\title{
A Comparative Study of Enterprising Tendency with the help of Select Cases in India
}

\author{
Dr.Hemantkumar P. Bulsara, Dr. Shailesh Gandhi and Dr. P. D. Porey
}

\begin{abstract}
Entrepreneurship is very crucial for every economy. While talking about Entrepreneurship, most of the people mainly focus on various aspects of business but forget about tendency towards entrepreneurial traits or characteristics. Enterprising Tendency is one of the most important parts of an Entrepreneurship. The aim of the paper is to study tendency towards entrepreneurial characteristics of entrepreneurs. In this paper, the comparative study of an Enterprising Tendency with the help of General Enterprising Tendency Test (GETT) and four cases in Gujarat, India was presented. The GETT was conducted on four lead entrepreneurs of the select cases. The result of the same are listed in the paper. The tendency towards characteristics of the entrepreneurs is also judged subjectively through analysis of the cases. Hence, both objective and subjective analysis are matched in the paper. The results show that there is considerable matching between both. This paper would be useful to understand importance and behavior of tendency towards entrepreneurial characteristics which are required to be a successful entrepreneur.
\end{abstract}

Index Terms-Enterprising Tendency, Entrepreneurship, Characteristics of an entrepreneur, GETT

\section{INTRODUCTION}

In Entrepreneurship, knowledge of all business functions is very important. Hence, when we talk about Entrepreneurship, main focus will be on various aspects of business like Product development, Feasibility analysis, Marketing, Finance, Human Resource Management and Manufacturing etc. But we tend to forget considering tendency towards entrepreneurial traits or characteristics. Enterprising Tendency is one of the most important parts of an Entrepreneurship. The aim of the paper is to study tendency towards entrepreneurial characteristics of entrepreneurs. This paper gives the comparative study of an Enterprising Tendency with the help of General Enterprising Tendency Test (GETT) and four cases in Gujarat, India. This paper will be useful to understand importance and behavior of tendency towards entrepreneurial characteristics which are required to be a successful entrepreneur. The GETT (General Enterprising Tendency Test) was used to judge the tendency of the entrepreneurs towards particular characteristics to be an entrepreneur. This test was developed by Durham Business School, UK and it is widely used test. It is used widely by DST (Department of Science

Dr.Hemantkumar P. Bulsara, Assistant Professor -Economics \& Management, S V National Institute of Technology, Surat, Gujarat, India 395007 (email: hbulsara@ashd.svnit.ac.in, hemantbulsara@gmail.com).

Dr. Shailesh Gandhi, Associate Professor \& Chairman - PGPX, Indian Institute of Management, IIM A,Ahmedabad, Gujarat, India 380015(email: shailesh@iimahd.ernet.in).

Dr. P. D. Porey, Professor, (Ex Director - SVNIT, Surat), VNIT, Nagpur, India(email: pdporey@svnit.ac.in). and Technology), Government of India in their programs related to the entrepreneurship promotion. EDII (Entrepreneurship Development Institute of India) also uses this test. We have also taken help of detailed case study of four cases in Gujarat, India. The result of the same are listed in the paper. The tendency towards characteristics of the entrepreneurs is also judged subjectively through analysis of the cases. Hence, both objective and subjective analysis are matched in the paper. The results show that there is considerable matching between both. The detailed description of all four cases would be out of scope of this paper but the brief presentation of all four cases is given in next section.

The four case studies are: Aura Herbal Textiles Limited Lead entrepreneur: Arun Baid, Nature Technocrats - Lead entrepreneur: Arvindbhai Patel and Mantis Technologies Lead entrepreneur: Aurvind Lama. All these ventures are established in Ahmedabad, Gujarat, India.

\section{Brief Presentation Of CAses}

Brief presentation of all four select cases is given as follows:

Case 1: Aura Herbal Textiles Limited

\begin{tabular}{|l|l|}
\hline Introduction & $\begin{array}{l}\text { Aura Herbal Textiles Limited is } \\
\text { certified by Global Organic Textile } \\
\text { Standard (GOTS) for their all } \\
\text { natural/herbal dyeing process. Dyeing } \\
\text { of fabrics up to 120' width was } \\
\text { achieved. Even lengths of up to 1000 } \\
\text { meters in different fabrics like voiles, } \\
\text { poplins, twills, flannels, corduroys, } \\
\text { denims, knits, silks was achieved at } \\
\text { Aura. }\end{array}$ \\
\hline $\begin{array}{l}\text { Founder's } \\
\text { Background }\end{array}$ & $\begin{array}{l}\text { Arun Baid: He was born in Rajasthan } \\
\text { in 1967, in Marwadi - community } \\
\text { known for business orientation in } \\
\text { India, wanted to be in business from } \\
\text { childhood. He did his B.Com, MBA } \\
\text { (Partial - left MBA for focusing on } \\
\text { business) and had experience of } \\
\text { chemical technology due to past } \\
\text { business of chemical recycling and } \\
\text { was very much interested in } \\
\text { environment } \\
\text { Sonal Baid: She is a wife of Arun } \\
\text { Baid and had experience of } \\
\text { international school, design, attended } \\
\text { herbal painting workshop. She got }\end{array}$ \\
\hline
\end{tabular}




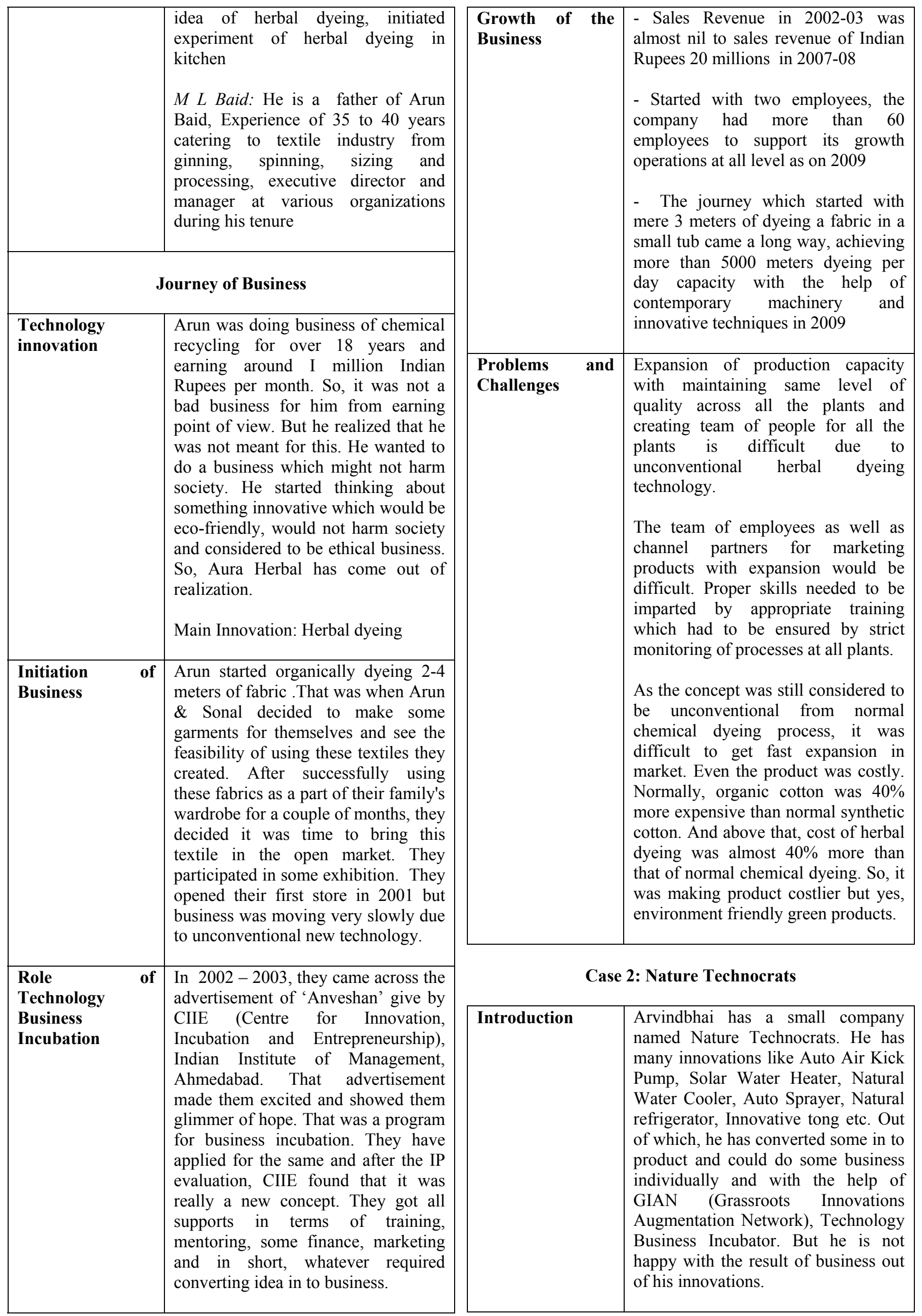




\begin{tabular}{|l|l|}
\hline Founder's & Arvindbhai: He was born in 1956 in \\
Vackground & India. He was poor in study, after 10 \\
standard did watch repairing technical \\
course from ITI (Industrial Training \\
Institute) for some time and left. He \\
also completed course on Automobile \\
engineering, got training at Ferguson \\
Tractor Company for 6 months. He \\
had hands on experience of Car \\
garage for 6 months, Diesel pump \\
injector service centre for 6 months, \\
instructor for Diesel Cum Mechanic \\
Mobile Classes started out of \\
Government scheme, a company - Al \\
Arfaz from Saudi Arabia job related \\
to technical maintenance. All these \\
job experience made him work and \\
handle the job independently.
\end{tabular}

\section{Journey of Business}

\begin{tabular}{|c|c|}
\hline $\begin{array}{l}\text { Technology } \\
\text { innovation }\end{array}$ & $\begin{array}{l}\text { He has many innovations like Auto } \\
\text { Air Kick Pump, Solar Water Heater, } \\
\text { Natural Water Cooler, Auto Sprayer, } \\
\text { Natural refrigerator, Innovative tong. } \\
\text { Most of the innovations have come } \\
\text { out of realization and prompt action } \\
\text { on them. }\end{array}$ \\
\hline $\begin{array}{l}\text { Initiation } \\
\text { Business }\end{array}$ & $\begin{array}{l}\text { In 1985, he purchased small industrial } \\
\text { shed near Ahmedabad for job work } \\
\text { with facilities like Lathe machines, } \\
\text { grinder, drilling machine and some } \\
\text { hand tools etc. Started manufacturing } \\
\text { Solar water heater without technical } \\
\text { details as seen in One engineering } \\
\text { college. He could not do well, so } \\
\text { closed the workshop in } 1987 \text {. } \\
\text { He started project of Auto Air Kick } \\
\text { Pump in } 1987 \text { with the help of one } \\
\text { fabricator but could not get success. } \\
\text { In 1988, he again started the project } \\
\text { of Solar water heater with } \\
\text { improvement. } \\
\text { In 1996, he initiated the project of his } \\
\text { innovation - Natural water cooler. } \\
\text { The GEDA (Gujarat Energy } \\
\text { Development Agency) was the main } \\
\text { customer. }\end{array}$ \\
\hline $\begin{array}{l}\text { Role } \\
\text { Technology } \\
\text { Business } \\
\text { Incubation }\end{array}$ & $\begin{array}{l}\text { In 1996, he could meet Chief } \\
\text { Innovation Manager of GIAN (Grass } \\
\text { root innovation Augmentation } \\
\text { Network), Technology Business } \\
\text { Incubator for Grassroots innovations. } \\
\text { He was invited to present his } \\
\text { innovations and selected for getting } \\
\text { support from GIAN. Details of } \\
\text { support were described in earlier } \\
\text { section. }\end{array}$ \\
\hline
\end{tabular}

\begin{tabular}{|c|c|}
\hline $\begin{array}{l}\text { Growth of the } \\
\text { Business }\end{array}$ & $\begin{array}{l}\text { - Mainly from one innovation to other } \\
\text { innovation but not in terms of } \\
\text { monetary gain. } \\
\text { - Got patents and some awards } \\
\text { including President of India award for } \\
\text { innovation }\end{array}$ \\
\hline $\begin{array}{ll}\text { Problems } & \text { and } \\
\text { Challenges } & \end{array}$ & $\begin{array}{l}\text { - Slow process of commercialization } \\
\text { which involves procedural delay } \\
\text { - Grassroots innovations involve more } \\
\text { risk, so getting fund is difficult } \\
\text { - Valuation of Technology transfer } \\
\text { - No formal training of business } \\
\text { functions } \\
\text { - Poor soft skills } \\
\text { - Copy of innovation } \\
\text { - Obsolescence of technology }\end{array}$ \\
\hline
\end{tabular}

\section{Case 3: Mantis Technologies}

\begin{tabular}{|l|l|}
\hline Introduction & $\begin{array}{l}\text { This company was established in the } \\
\text { year } 2007 \text { and growing very fast. With } \\
\text { the help of SAAS (Software As A } \\
\text { Service) based model, the bus service } \\
\text { operators were integrated which gave } \\
\text { many advantages to (1) Bus operators, } \\
\text { (2) Travel agents and (3) Customers. } \\
\text { The application was run through } \\
\text { www.travelyaari.com as platform for } \\
\text { booking of bus tickets. Mantis } \\
\text { developed state of the art global } \\
\text { distribution system (called Mantis } \\
\text { Connect) which turned out to be the } \\
\text { lifeline of Western Indian bus } \\
\text { industry. Mantis pioneered in } \\
\text { developing a dynamic bus global } \\
\text { distribution system in India. }\end{array}$ \\
\hline Founder's \\
Background & $\begin{array}{l}\text { Aurvind Lama: he was born in 1981 in } \\
\text { Orissa, India. His father was an } \\
\text { engineer and in Government service } \\
\text { with transferable job. So even, } \\
\text { Aurvind had to travel a lot with his } \\
\text { family. He did B.Tech. from Indian } \\
\text { Institute of Information Technology, } \\
\text { Allahabad, MBA from Indian Institute } \\
\text { of Management Ahmedabad. He has } \\
\text { experience of Infosys as a software } \\
\text { engineer, Tech - mahindara and } \\
\text { Honeywell as a Senior Consultant for } \\
\text { Technology solutions and Business } \\
\text { solutions, got training in DPWN- } \\
\text { vendor analysis of logistic software }\end{array}$ \\
\hline
\end{tabular}




\begin{tabular}{|c|c|c|c|}
\hline & $\begin{array}{l}\text { provider. } \\
\text { He is supported by Parthasarathi } \\
\text { Sinha, Pratik Nigam and Rajiv } \\
\text { Dhamsania. }\end{array}$ & & $\begin{array}{l}\text { operators. Bus operators showed } \\
\text { interest and that has created the } \\
\text { company-mantis Technologies. } \\
\text { They started the business in } 2007\end{array}$ \\
\hline \multicolumn{2}{|r|}{ Journey of Business } & & $\begin{array}{l}\text { with their own funds of Indian Rupees } \\
100000 \text { as an initial investment which }\end{array}$ \\
\hline \multirow[t]{2}{*}{$\begin{array}{l}\text { Technology } \\
\text { innovation }\end{array}$} & \multirow{2}{*}{$\begin{array}{l}\text { With the help of SAAS (Software As } \\
\text { A Service) based model, the bus } \\
\text { service operators were integrated } \\
\text { which gave many advantages to (1) } \\
\text { Bus operators, (2) Travel agents and } \\
\text { (3) Customers. The application was } \\
\text { run through www.travelyaari.com as } \\
\text { platform for booking of bus tickets. } \\
\text { Mantis developed state of the art } \\
\text { global distribution system (called } \\
\text { Mantis Connect). Mantis pioneered in } \\
\text { developing a dynamic bus global } \\
\text { distribution system in India. }\end{array}$} & & $\begin{array}{l}\text { Some fund they have got from } \\
\text { relatives' of partners and took bank } \\
\text { loan. They never contacted any } \\
\text { venture capitalists for fund due to fear } \\
\text { of loosing control before building a } \\
\text { robust business model. Aurvind and } \\
\text { Partha continued working for their } \\
\text { employer to pump in fund for their } \\
\text { own organization. }\end{array}$ \\
\hline & & \multirow[t]{2}{*}{$\begin{array}{l}\text { Growth of the } \\
\text { Business }\end{array}$} & $\begin{array}{l}\text { Employees: In } 2006-07 \text { - partners and } \\
\text { only } 2 \text { employees for field support and } \\
\text { in 2008-09- Partners and } 20 \\
\text { employees for various business }\end{array}$ \\
\hline \multirow[t]{2}{*}{$\begin{array}{l}\text { Initiation } \\
\text { Business }\end{array}$} & \multirow{2}{*}{$\begin{array}{l}\text { Aurvind never thought to be an } \\
\text { entrepreneur. He wanted a peaceful } \\
\text { life. He wanted to have a good salary } \\
\text { job. } \\
\text { Then, the real turning point in the life } \\
\text { of Aurvind came when he was in the } \\
\text { internship at DPWN (Deutsche Post } \\
\text { World Net - Now Deutsche Post } \\
\text { DHL) in Germany for } 2 \text { months after } \\
\text { completion of } 1^{\text {st year of MBA. It was }} \\
\text { one of the best companies in Logistic } \\
\text { and Supply Chain Management } \\
\text { industry. He got assignment of vendor } \\
\text { analysis and auditing of one Hong } \\
\text { Kong based Software Company. He } \\
\text { had to audit the project in terms of } \\
\text { product and process, set up and cost } \\
\text { estimation. His Infosys experience } \\
\text { helped him a lot there. That } \\
\text { experience of just two months } \\
\text { increased his confidence and } \\
\text { realization of opportunity. } \\
\text { After coming back from training, he }\end{array}$} & & $\begin{array}{l}\text { functions } \\
\text { Business span: In } 2006-07 \text { - only } \\
\text { Gujarat and in } 2008-09-6 \text { states of } \\
\text { India, from } 2-3 \text { bus operators to more } \\
\text { than } 30 \text { bus operators in } 2008-09 \\
\text { Revenue: Indian Rupees } 10000 \text { / } \\
\text { month in } 2006-07 \text { to Indian Rupees } \\
1500000 / \text { month in } 2008-09\end{array}$ \\
\hline & & $\begin{array}{l}\text { Problems and } \\
\text { Challenges }\end{array}$ & $\begin{array}{l}\text { - Expansion and with expansion } \\
\text { increase in operation cost } \\
\text { - Funding expansion with the help of } \\
\text { VC but fear of loosing control } \\
\text { - Competition in travel industry } \\
\text { - Building a team of employees and } \\
\text { channel partners with expansion } \\
\text { - Continuous innovation in all aspect } \\
\text { of business }\end{array}$ \\
\hline
\end{tabular}
met his friend Partha at IIMA whom he had trust and faith. He told Partha to do something about his idea generated through the experience he got from DPWN.

They thought that good option might be to go in to Bus Ticket Market as there were many private Bus Operators doing business individually with the help of branches and agents. So integrating these Bus operators was an opportunity.

With help of his team of partners they developed the Software and met bus

Case 4: Phoenix Soft Toys Creation

\begin{tabular}{|l|l|}
\hline Introduction & $\begin{array}{l}\text { This is a case of Kinnari Parikh, } \\
\text { owner of Phoenix Soft Toys Creation, } \\
\text { was born in 1959. She started her } \\
\text { business with Soft toys and used soft } \\
\text { toys in education. Then, she has } \\
\text { introduced puppet in her business. As } \\
\text { on 2009, she had more than 100 } \\
\text { varieties of soft toys and more than } \\
90 \text { varieties of puppets. }\end{array}$ \\
\hline $\begin{array}{l}\text { Founder's } \\
\text { Background }\end{array}$ & $\begin{array}{l}\text { Kinnari Parikh is from a traditional } \\
\text { Gandhian culture driven family from }\end{array}$ \\
\hline
\end{tabular}




\begin{tabular}{|c|c|}
\hline & $\begin{array}{l}\text { a village Chorwad (Gujarat - India), } \\
\text { the land of Dhirubhai Ambani, One } \\
\text { of the biggest Entrepreneur in India. } \\
\text { Her family was in farming during his } \\
\text { child hood. She was influenced by } \\
\text { good books. She visited places of } \\
\text { inspirations. She was a family } \\
\text { oriented person. She did B.Sc., got } \\
\text { training from EDII (Entrepreneurship } \\
\text { Development Institute of India) in } \\
\text { from of small workshop, had hobby } \\
\text { of making soft toys. She was married } \\
\text { to a doctor. }\end{array}$ \\
\hline \multicolumn{2}{|r|}{ Journey of Business } \\
\hline $\begin{array}{l}\text { Technology } \\
\text { innovation }\end{array}$ & $\begin{array}{l}\text { Soft toys and Puppets may not come } \\
\text { in to category of Technology business } \\
\text { but she developed a model of training } \\
\text { and education though Soft Toys and } \\
\text { Puppet. That was innovative. }\end{array}$ \\
\hline $\begin{array}{l}\text { Initiation } \\
\text { Business }\end{array}$ & $\begin{array}{l}\text { In the final year of B.Sc., one of her } \\
\text { friends came to Mumbai to get } \\
\text { trained in Toy making. She, in turn, } \\
\text { trained her to make toy horse which } \\
\text { she sold it to a shop with great } \\
\text { difficulty for Rs.5. Later, she saw the } \\
\text { same horse being sold for Rs. } 22 \text { to } \\
\text { another customer. This incident was a } \\
\text { great learning for her to understand } \\
\text { her actual potential to start something } \\
\text { on her own. } \\
\text { Within few months of marriage, she } \\
\text { joined the course of toy making from } \\
\text { Miss Bani Singaporewala. In } 1980 \text {, as } \\
\text { a hobby, she started making toys for } \\
\text { her home. } \\
\text { She started making toys for her } \\
\text { husband's children clinic and the } \\
\text { people visiting the clinic appreciated } \\
\text { it. }\end{array}$ \\
\hline $\begin{array}{l}\text { Growth of the } \\
\text { Business }\end{array}$ & $\begin{array}{l}\text { She started with just } 3 \text { students in } \\
1993 \text { which has increased to } 15 \text { by } \\
\text { year end and total revenue through } \\
\text { sales and fees was just Indian Rupees } \\
20000 \text { but could increase well in } \\
\text { between. But revenue had gone down } \\
\text { in recent past due to family }\end{array}$ \\
\hline
\end{tabular}

\begin{tabular}{|c|c|}
\hline & $\begin{array}{l}\text { responsibility as a female, illness. } \\
\text { Actually, she personally was happy } \\
\text { with small business. }\end{array}$ \\
\hline $\begin{array}{ll}\text { Problems and } \\
\text { Challenges }\end{array}$ & $\begin{array}{l}\text { - It was always difficult for her to } \\
\text { maintain balance among family, } \\
\text { personal interests, social contribution } \\
\text { and business. } \\
\text { - Keeping her classes on had always } \\
\text { been a challenge because of the } \\
\text { competition she had been facing in } \\
\text { terms of professional and hobby } \\
\text { classes. } \\
\text { - Her business required continuous } \\
\text { redesign in terms of product, } \\
\text { manufacturing, personnel and training } \\
\text { modules. } \\
\text { - As she studied in Gujarati medium, } \\
\text { it is difficult for her to convey the } \\
\text { message of education through puppet } \\
\text { in modern era which built around } \\
\text { English in most of the education } \\
\text { institutions. }\end{array}$ \\
\hline
\end{tabular}

\section{LITERATURE REVIEW}

The Characteristics of an Entrepreneur or Entrepreneurial traits have been given by different researchers in different manner. Charntimath Purnima (2006) emphasized on following major characteristics that one successful entrepreneur should have: Creativity, Innovation, Dynamism, Leadership, Teambuilding, Achievement motivation, Problem solving, Goal orientation, Risk taking and decision making ability, Commitment Sasi Misra and E. Sendil Kumar (2000) gave the characteristics in unique way as follows: Cognitive Competence (Ability to analyze and make sense of large volumes of information, Ability to take risks, Innovativeness, Ability to perceive and make sense of equivocal realities, Tolerance for equivocality and uncertainty, high effort-outcome expectancy), Affective competence (Ability to control feelings of withdrawal and depression, Competitive desire to excel, Ability to persevere, High central life interest, Dissatisfaction with status quo), Action-oriented competence (Ability to take charge and lead employees, Ability to influence external agencies, Ability to find, marshal and control resources, Ability to establish strong networks). A successful entrepreneur must be a person with technical competence, initiative, good judgment, intelligence, leadership qualities, self confidence, energy, attitude, creativeness, fairness, honesty, tactfulness and emotional stability (Desai V., 2001). Negotiating skills, technical skills, the ability to sell their vision to others, ability to motivate people, passion are some of the important characteristics of an entrepreneur (Entrepreneurs' toolkit, Harvard Business essential, 2005). 


\section{ANALYSIS AND FINDINGS}

In the Literature Review; the details of the characteristics of an entrepreneur, given by some of the researchers, have already been discussed which would help in analysis of the results of the GETT.

The results of this test for different entrepreneurs for select cases are as follows:

TABLE I. COMPARATIVE STUDY OF CHARACTERISTICS OF ENTREPRENEURS

\begin{tabular}{|c|c|c|c|c|c|}
\hline \multirow[t]{2}{*}{ Characteristics } & \multirow[t]{2}{*}{$\begin{array}{l}\text { Range of } \\
\text { Score }\end{array}$} & \multicolumn{4}{|c|}{$\begin{array}{l}\text { Actual Score } \\
\text { (Tendency) }\end{array}$} \\
\hline & & $\begin{array}{c}\text { Case } \\
1\end{array}$ & $\begin{array}{c}\text { Case } \\
2\end{array}$ & $\begin{array}{c}\text { Case } \\
3\end{array}$ & $\begin{array}{c}\text { Case } \\
4\end{array}$ \\
\hline $\begin{array}{ll}\text { Need } & \text { for } \\
\text { Achievement } & \end{array}$ & $\begin{array}{l}\text { Maximum:12 } \\
\text { Average: } 9\end{array}$ & 10 & 12 & 12 & 10 \\
\hline $\begin{array}{lr}\text { Need for } \\
\text { autonomy } \\
\text { independence }\end{array}$ & $\begin{array}{l}\text { Maximum:6 } \\
\text { Average: } 4\end{array}$ & 05 & 06 & 04 & 04 \\
\hline Creative tendency & $\begin{array}{l}\text { Maximum: } 12 \\
\text { Average: } 8\end{array}$ & 08 & 11 & 10 & 09 \\
\hline $\begin{array}{lr}\text { Moderate } & / \\
\text { calculated } \\
\text { taking }\end{array}$ & $\begin{array}{l}\text { Maximum: } 12 \\
\text { Average: } 8\end{array}$ & 10 & 09 & 11 & 09 \\
\hline $\begin{array}{l}\text { Drive and } \\
\text { determination }\end{array}$ & $\begin{array}{l}\text { Maximum: } 12 \\
\text { Average :8 }\end{array}$ & 12 & 09 & 12 & 10 \\
\hline
\end{tabular}

\section{Description and findings:}

The results of the GETT, with findings from the select cases, are described as follows:

Need for Achievement: As given in the test, it includes the sub characteristics like: Forward looking, Self-sufficient, Optimistic rather than pessimistic, Task oriented, Result oriented, Restless and energetic, Self-confident, Persistent and determined, Dedication to completing a task. Purnima (2006) has given that entrepreneurs should have Achievement motivation and Sasi Misra et al (2000) has given importance to Affective competence. Desai V (2001) has given importance to self confidence and energy. These would have some matching with the sub characteristics given in Need for Achievement. It can be seen from the score that all entrepreneurs scored above average in this category. Arvindbhai and Aurvind Lama scored the maximum in this category. They had extremely high need for achievement. In the case of Arvindbhai, that had motivated him to pursue more and more innovations continuously, though he was not successful in business. Both Arvindbhai and Aurvind Lama showed lot of confidence in their innovations out of realization and acted promptly. Hence, Mantis Technologies could achieve fast growth in just two years. But Arvindbhai did not have appropriate soft skills to develop effective business. So, his very high need for achievement was focused more on creating new innovations rather than business development. In the case of Arun Baid, her wife made him acted promptly for their innovation of herbal dyeing and as a team they could achieve good growth of the business. Kinnari Parikh showed confidence in his innovative products out of hobbies but her need for achievement was not so high, so she could not grow her business even after many years. She herself told that she would like to have small business only.

Need for autonomy / independence: it includes the sub characteristics like: Likes doing unconventional things, Prefers working alone, Needs to do 'own thing', Needs to express what he / she thinks, Dislikes taking orders, Likes to make up own mind, Does not bow to group pressure, Stubborn and determined. All entrepreneurs have scored on and above average in this category. Arvindbhai had highest tendency toward need for autonomy. That may be the reason; he could not build the team of partners for his business development and tried to do everything alone without taking any partners. He was lacking soft skills and business functional knowledge. He could have taken professional partners in his business but he never thought of that. So, he could become very good innovator but could not become good businessman. Even, it made him like doing unconventional things and from case; it was proven that he made many unconventional innovations. Arun and Aurvind both had very good team of partners in their business venture. But Arun had good score in this category which made him entrepreneurs as he never wanted to work for some body. Aurvind Lama had average score, which may be the reason that he preferred to do job initially. But high need for achievement made him entrepreneur. In the case of Kinnari Parikh, her need for independence was average which is fine for small business which she was handling with managing her home as home maker woman, involving her in some social work etc.

Creative tendency: It includes: Imaginative and innovative, Tendency to day dream, Versatile and curious, Lots of ideas, Intuitive and can guess well, Enjoy new challenges, Likes novelty and change. Purnima (2006) has shown that creativity is an important characteristic for an entrepreneur. Even Desai V. (2001) has shown importance to creativeness and Sasi Misra et al (2000) has covered this in Cognitive Competence. All entrepreneurs scored on and above average score in this category. Arvindbhai scored very high in this category and from case also, it was proven that he had many innovations like Auto Air Kick Pump, Solar Water Heater, Natural Water Cooler, Auto Sprayer, Natural refrigerator, Innovative tong. So, his score justifies that. Creative tendency of Arun was average but he was helped by his wife Sonal Baid by bringing innovative idea about herbal dyeing. He built business around that idea brought by her wife. Creative tendency of Aurvind was high and that may be the reason, he though of innovative SaaS model for hid business during his training at DPWN. And that created Mantis Technologies to integrate and support private bus services in India. Kinnari Parikh's creative tendency was also high and because of that only she could derive a model of using soft toys and puppet in education and training.

Moderate / calculated risk talking: It includes: Act on incomplete information, Judge when incomplete data is sufficient, Accurately assesses own capabilities, Be neither over nor under-ambitious, Evaluate likely benefit against likely costs, Set challenging but attainable goals. Purnima (2006) and Sasi Misra et al (2000) both have given importance to this characteristic. Sasi Misra has shown that in Cognitive competence. All the entrepreneurs scored on and above average in this category. Arun Baid and Aurvind 
Lama had high risk taking ability. That may be the reason; they invested comparatively higher capital in their business though the innovations were comparatively unconventional with amount of risk involved. But the risk was moderate and well calculated, so they could get growth in their business in their respective ventures: Aura Herbal and Mantis Technologies. But in the case of Arvindbhai and Kinnari Parikh, they had nearly average score in this category of risk. That may be the reason, they did not invest higher capital in their business and business could not grow properly without proper investment.

Drive and determination: It includes: Take advantage of opportunities, Discount fate, Make own luck, Be selfconfident, Believe in controlling own destiny, Equate results with effort, Show considerable determination. In this category, again all entrepreneurs scored on and above average. But Arun Baid of Aura Herbal and Aurvind Lama of Mantis Technologies had very strong drive and determination. Which may be the reason; they could grow their business very well. In the case of Arvindbhai and Kinnari Parikh, the scores were nearly average. That may be the reason; they could not grow their business.

From above scores of GETT, it is seen that all the lead entrepreneurs considered here had scored on and above average score to be obtained for showing tendency towards entrepreneurship. That may be the reason; all of them chose to be entrepreneurs.

Other parameters: Apart from GETT scores, from only cases, some other parameters were found which can be tested in future study.

'Realization of innovation and prompt action on that' is another parameter come out of present study. In case of Aura Herbal, they realized of environmental friendly product. After attending training of Herbal Fabric Painting, they started experimentation in the kitchen and that shows prompt action on realization. In case of Nature Technocrats, Arvindbhai made almost all of his innovations out of realization and prompt action on that. When he got fever, her wife was putting wet cloth on his head and after some time his head got cool. He realized the concept of evaporation out of that and acted promptly to innovate the Natural water cooler out of that. He got puncture on road and faced the problem of filling air in the tyre, so he came out with Auto Air Kick pump. In the case of Mantis Technologies, during his training at DPWN, Aurvind realized that he could build logistics software based on SaaS model which could serve Indian Bus services. He came to India and acted promptly on that and they created Mantis Technologies.

'Building a Team' is also an important parameter come out of study of the cases. Purnima (2006) also support this. In case of Aura Herbal and Mantis Technologies, they built very good team of partners to develop business out of their technology innovations. But in case of Nature Technocrats, Arvindbhai had very good innovations but he could not build a good team of partners to support his technology innovations. He was lacking in soft skills and business functional knowledge but this problem could have been solved by having good team in his business.

\section{CONCLUSION}

Building a business with the help of various business functions like Product development, Feasibility analysis, Marketing, Finance, Human Resource Management and Manufacturing is very important. But Enterprising Tendency is equally important. Entrepreneur may have all business functional knowledge but he / she may get failure is he / she does not have required tendency towards entrepreneurial characteristics. We could see from this paper how Tendency towards entrepreneurial characteristics plays a role in shaping a business. We could see that there is considerable matching between objective and subjective analysis of Tendency towards the entrepreneurial characteristics. From both objective analysis through GETT (General Enterprising Tendency Test) and subjective analysis through Case study, we could see that Need for Achievement, Need for autonomy / independence, Creative tendency, Moderate / calculated risk talking, Drive and determination and other parameters like: Realization of innovation and prompt action on that, Building a Team are really important for the successful entrepreneurial venture. These will decide success and failure of any enterprises many times. Hence, while building a business, one must consider tendency towards all above characteristics and parameters apart from all essential business functions for the success of enterprise. There is a scope of future empirical research with appropriate sample size to test all above enterprising tendency parameters and even other parameters from the cases.

\section{REFERENCES}

[1] Bhandari N.C., Intention for Entrepreneurship among Students in India, The Journal of Entrepreneurship,15,2 (2006), Sage Publications, Los Angeles/London/New Delhi/ Singapore, pp 169 179, 2006 (http://joe.sagepub.com/cgi/content/abstract/15/2/169)

[2] Bhattacharya D. K., Research Methodology, Excel Books, New Delhi, $2^{\text {nd }}$ Edition, 2006

[3] Charantimath P., Entrepreneurship Development Small Business Enterprise, Pearson Education, New Delhi, pp 48-96, 2006

[4] Cooper D. R. \& Schindler P. S., Business Research Methods, Tata McGraw-Hill Publishing Company Limited, New Delhi, $8^{\text {th }}$ Edition, 2004

[5] Das M., Women Entrepreneurs from Southern India: An Exploratory study, The Journal of Entrepreneurship, 8, 2(1999), Sage Publications, Los Angeles/London/NewDelhi/Singapore,pp147-163, 1999 (http://joe.sagepub.com/cgi/content/abstract/8/2/147)

[6] Desai A. N., Environment and Entrepreneur, Ashish Publishing House, New Delhi, 1989

[7] Desai V., Small -scale industries and Entrepreneurship, Himalaya Publishing House, India, 2005

[8] Desai V., Dynamics of Entrepreneurial Development and Management, Himalaya Publishing House, Mumbai, 2001

[9] Entrepreneurial Competencies: a synoptic view, Reading Material for Faculty Development Programme in Entrepreneurship during December 19 - 30, 2005, Entrepreneurship Development Institute of India (EDII), Ahmedabad, Vol.1, pp 191 - 211, December 2005

[10] Entrepreneurs' toolkit, Harvard Business essential, 2005

[11] Galloway L. and Mochrie R., Entrepreneurial motivation, orientation and realization in rural economies - A study of rural Scotland, International Journal of Entrepreneurship and Innovation, Vol 7, No 3, I P Publishing, U K, pp 173-183, 2006

[12] General Enterprising Tendency Test (GETT), Durham University Business School, April 1988

[13] Misra, S. and Sendil Kumar, E., Resourcefulness: A Proximal Conceptualisation of Entrepreneurial Behaviour, The Journal of Entrepreneurship, Sage Publication, New Delhi/ Thousand Oaks/ London, 9, 2 and references there in, 2000

[14] Yin R. K., Applications of Case Study Research, Sage Publications, USA, $2^{\text {nd }}$ Edition, 2003 
[15] Yin R. K. , Case Study Research, Sage Publications, USA, $3^{\text {rd }}$ Edition, 2003

[16] Sherry Chand V. and Gita A. C., Teachers and Socio-educational Entrepreneurship: Competence as a Consequence, The Journal of Entrepreneurship, 15, 2 (2006), Sage Publications, Los Angeles/London/New Delhi/ Singapore, pp 97 - 114 , 2006 (http://joe.sagepub.com/cgi/content/abstract/15/2/97)

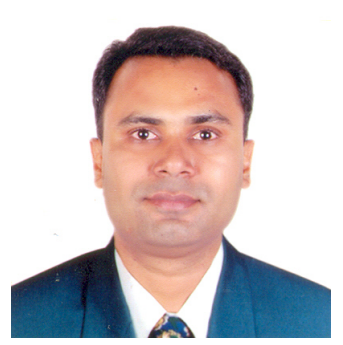

Dr. Hemantkumar P. Bulsara was born in 1974 in Mumbai, India. He has completed his graduation in Production Engineering in 1997 and then completed his MBA in 2000. He has also completed extensive Faculty Development Program in Management from Indian Institute of Management, Ahmedabad, India (IIM A). In 2010, he has completed his $\mathrm{PhD}$ in Management from S V National Institute of Technology, Surat, India. His area of research, in $\mathrm{PhD}$, was: Techno-innovations to Techno-Entrepreneurship through Technology Business Incubation.

Hemant has more than 11 years of experience, mainly in academics and some in Industry \& Research - Consultancy. He has been teaching to Engineering and Technology students as well as MBA students. At present, he is serving as an Assistant Professor (Economics \& Management) at S V National Institute of Technology (NIT Surat), one of the leading Technology Institutes in India. He has served for Entrepreneurship Development Cell also before serving for one MNC for a short period. Apart from normal academic activities, he has been involved in many administration activities too. He has around 20 publications in National and International Journals, Proceedings and Edited volumes etc. [including publication in Asia Pacific Journal of Innovation and Entrepreneurship (published by AABI), IEEE Press (Indexed by Thomson ISI), Indian Journal of Technical Education, CURIE Journal - BITS Pilani, Asia Pacific Tech Monitor Journal (www.techmonitor.net), Asian and Pacific Centre for Transfer of Technology (APCTT) of the United Nations Economic and Social Commission for Asia and the Pacific (UNESCAP) etc.] He has participated in more than 35 Seminars, Workshops, Conferences and Developments [including programs / seminars / conferences at IIMs, IITs, NITs, EDII, United Nations University Netherlands, ICTP - Italy]. Hemant has delivered / presented more than 30 expert lectures / papers in the National and International Seminar, workshop, training programs, conferences etc. [including two paper presentations at ICIM 2008 - United Nations University - Netherlands and one in ICEME 2010 at Hong Kong]. He was a Key note speaker in ICEME 2010, Hong Kong. His main research interest is in the area of Innovations and Entrepreneurship but he is also interested in the research area of Marketing and Operations. He is very much interested in solving problems and handling projects from Industry.

Dr. Bulsara is a member of All India Management Association (AIMA), NACCE (National Association of Community Colleges of Entrepreneurship), USA and Indian Institution of Industrial Engineering. $\mathrm{He}$ is in the Editorial Board and Reviewer to the some academic journals. 